\title{
The engineering and pedagogical workers' professional development: lessons from training needs analysis
}

\author{
Aida Tologonova ${ }^{1 *}$, Rahat Bekboeva ${ }^{2}$, and Damira Alibaeva ${ }^{3}$ \\ ${ }^{1}$ Kyrgyz State University of Construction, Transport and Architecture, Bishkek, Kyrgyz Republic \\ ${ }^{2}$ The International University of Kyrgyz Republic, Bishkek, Kyrgyz Republic \\ ${ }^{3}$ Ministry of Education and Science, Bishkek, Kyrgyz Republic
}

\begin{abstract}
The article reflects the results of the needs analysis for training of engineering and pedagogical workers of construction educational institutions of the Kyrgyz Republic, based on the methodology for assessing the professional competencies of engineering and pedagogical workers for the compliance of their knowledge and skills with the criteria for performing work laid down in professional standards in the Specialty and in Pedagogy. It was revealed that there is a certain gap between the necessary (by professional standards) and available professional competencies of engineering and teaching workers. The methodology under consideration will allow the management of educational institutions to constantly monitor the level of professional competencies of engineering and pedagogical workers, to identify the missing competencies of engineering and pedagogical workers, and to form an individual trajectory of professional development.
\end{abstract}

\section{Introduction}

One of the key elements of ensuring the quality of vocational education is the high qualification of the engineering and pedagogical workers, which is achieved by constant professional development. Labor market requirements for the professional workers are constantly changing and this is due to the development of new technologies, international labor migration and a digital economy. Technological progress forces enterprises to constantly update equipment, and very often the engineering and pedagogical workers remain on the acquired knowledge and competencies that do not meet the requirements of the developing labor market.

It becomes necessary to constantly monitor the level of the engineering and pedagogical workers' professional competencies, find the missing competencies and improve the qualifications of the engineering and pedagogical workers through the development of teacher-training program. A theoretical approach to integrating the needs of training analysis into teacher training programs is considered by H. Moeini [1]

Professional competencies for engineering and pedagogical workers in the specific professional area are described in professional standards, which are developed by professional associations of employers and are constantly updated. But almost always there 
is a certain gap between the necessary (according to the professional standard) and the available professional competencies of the engineering and pedagogical workers, since the technological processes and materials are constantly changing. Determination of this level of competence-based compliance or non-compliance will allow the engineering and pedagogical workers to form its own individual trajectory of professional development. SelfAssessment against Professional Standards was conducted by the UK Education and Training Foundation $[2,3]$.

In this article, to the engineering and pedagogical workers training needs analysis was used the approach, according to which the engineering and pedagogical workers must meet the requirements of two professional standards, namely the Professional standard in the "Specialty" and the "Pedagogy" professional standard. So, for example, an engineering and pedagogical worker specializing in "Installation and operation of internal sanitary and ventilation devices" must meet the requirements of the Professional standard for the engineering worker for the installation and operation of internal sanitary and ventilation devices, as well as of the Professional standard of "Pedagogy". At the same time, in addition to professional competencies for successful work, modern engineering and pedagogical workers' requires so-called "general" skills: social skills (teamwork, communication), emotional skills (stress resistance, non-burnout at work), intellectual skills (motivation for professional development, independence), etc. This approach forms the basis of the engineering and pedagogical workers professional competencies' assessment methodology that developed by the authors of this article [4].

\section{Research methods}

To assess the engineering and pedagogical workers' professional competence is used the method of analyzing text documents, namely Professional standards. The main survey method of engineering and pedagogical workers is the creation of an online questionnaire.

\section{Results and Discussion}

In August-September 2020, the engineering and pedagogical workers training needs analysis was conducted in 8 educational institutions of secondary vocational education (183 people), including the Bishkek College of Architecture, Management and Construction (BCAMC). In the system of secondary vocational education, the engineering and pedagogical workers means the administration, teachers, the master of practical training who take part in the organization, conducting and methodological support of the educational process to train and retrain mid-level specialists.

The goal was determining the needs of an engineering and pedagogical workers in training in order to achieve and implement the necessary professional competencies of the qualification level.

The training needs analysis was based on the following general principles:

- Objectivity - an impartial, unbiased attitude towards the engineering and teaching worker and to his activities in the educational institution;

- Uniformity - a list of assessment indicators and criteria established according to a single model;

- Transparency - an open procedure for the training needs analysis of an engineering and pedagogical worker with an explanation of the obtained results.

Within the framework of the study, 3 criteria of compliance (assessment) of the engineering and pedagogical workers' competencies were used: 
1. The Professional standards for the successful solution of specific professional tasks;

2. The Pedagogy standards for solving specific problems of pedagogical activity;

3. The key general competencies for the successful solution of problems common to professional and pedagogical professional activities.

The criterion for assessing the professional competencies, for example, of the engineering and pedagogical worker specializing in "Installation and operation of internal sanitary and ventilation devices" were taken from the Professional standard "The installation and operation of internal sanitary and ventilation devices", namely [5]:

1. Participation in the water supply and sanitation systems design;

2. Participation in the heat supply and heating systems design;

3. Participation in the ventilation and air conditioning systems design;

4. Planning and preparation of systems and facilities for installation, operation and repair;

5. Organization and execution of water supply and sewerage systems, heating, ventilation and air conditioning installation works;

6. Organization and control of water supply and sewerage systems, heating, ventilation and air conditioning commissioning;

7. Organization and control of water supply and sewerage systems, heating, ventilation and air conditioning operation;

8. Production supervision and control over the repair of engineering networks and equipment of construction sites.

For assessing the pedagogical competencies of the engineering and pedagogical worker, the next criteria were taken [6]:

1. Teaching and learning;

2. Methodological support of the educational process;

3. Support of students' project activities;

4. Studying the labor market and students' requirements to the quality of education and conducting career guidance activities.

The following general competencies, common to professional and pedagogical professional activities, were taken:

1. The ability to establish pedagogically meaningful relationships with colleagues and learners;

2. The ability to use digital technologies in the educational process;

3. Compliance with the requirements of labor protection, industrial sanitation and fire safety;

4. The ability to develop in professional activities throughout life.

5. The ability to successfully and efficiently ensure the achievement of learning outcomes in their subject;

6. The ability to observe labor discipline;

7. The ability to independently plan and perform work, without specific instructions from the supervisor, colleagues, within the competence and responsibility defined in the job descriptions;

8. The ability to be analytical and creative in making decisions or preparing proposals for solving a problem;

9. The ability to take initiative and responsibility in planning and performing work, within the competence and responsibility defined in job descriptions.

When determining the results of the assessment, a five-point scale of assessments is used from 2 to 5. For each criterion, an assessment was given:

- 5 points "Excellent" - the engineering and pedagogical worker meets the requirements (no comments); 
- 4 points "Good" - the engineering and pedagogical worker meets the requirements, but there are some comments;

- 3 points "Satisfactory"- the engineering and pedagogical worker does not always fulfill the requirements;

- 2 points "Unsatisfactory" - the engineering and pedagogical worker does not meet the requirements.

The assessment of the engineering and pedagogical worker professional, pedagogical and general competencies was carried out on the basis of the results:

- The engineering and pedagogical workers' self-assessment,

- Survey of students, colleagues and administration.

If the engineering and pedagogical worker is assessed below "Satisfactory" for any component, he was proposed to improve the qualification level through training and / or retraining.

Upon receiving a rating of "Satisfactory" and "Good", the engineering and pedagogical worker was recommended to take in-service courses and / or internship.

Upon receiving an "Excellent" grade, the engineering and pedagogical worker was recommended to motivate.

The results of the training needs analysis in the professional component showed that engineering and pedagogical worker need mainly the development of the following competencies:

- The basics of calculating water supply and sewerage systems were completed using professional computer programs based on technical specifications, architectural and construction drawings and current building codes and regulations;

- The basics of calculating heat supply and heating systems were completed using professional computer programs based on technical specifications, architectural and construction drawings and current building codes and regulations;

- Organized and carried out the quality control of installation work;

- The monitoring and diagnostics of the parameters of the operational suitability of systems and equipment of water supply, water disposal, heating, ventilation and air conditioning were carried out.

Table 1 illustrates the training modules are recommended by the authors to develop the competencies of engineering and pedagogical worker in the pedagogical component.

Table 1. Training modules.

\begin{tabular}{|c|c|}
\hline Competencies & Training modules \\
\hline Apply modern teaching and learning methods & \multirow{3}{*}{$\begin{array}{l}\text { Teaching and Learning, } \\
\text { including "Student-Centered } \\
\text { Learning, Teaching and } \\
\text { Assessment" }\end{array}$} \\
\hline $\begin{array}{l}\text { Form students' practical skills in analyzing } \\
\text { professional activities, choosing ways to solve the } \\
\text { assigned professional tasks from the recommended } \\
\text { options }\end{array}$ & \\
\hline $\begin{array}{l}\text { Allow students to share responsibility for shaping their } \\
\text { curriculum and assessing their academic achievements }\end{array}$ & \\
\hline $\begin{array}{l}\text { Plan and implement effective training programs in a } \\
\text { safe and inclusive environment for different groups or } \\
\text { individuals }\end{array}$ & $\begin{array}{l}\text { Methodological support for the } \\
\text { educational program's } \\
\text { implementation }\end{array}$ \\
\hline Develop teaching practice using educational research & Pedagogical research methods \\
\hline Plan and implement project-based learning & Project-based learning \\
\hline
\end{tabular}




\begin{tabular}{|l|}
\hline $\begin{array}{l}\text { Creativity and innovation in the selection and } \\
\text { adaptation of strategies to assist students in learning }\end{array}$ \\
\hline Maintain and update teaching and learning \\
experiences and professional skills through \\
collaboration with employers \\
\hline Promote organizational development and quality \\
assurance by studying and meeting the requirements of \\
the labor market and learners \\
\hline Plan and implement career guidance work
\end{tabular}

The results of the survey on the key general competencies component showed that the vast majority of engineering and pedagogical workers have needs to develop the following key general competencies:

- Reveal the benefits of modern digital technologies and support students in using the achievements of modern digital technologies;

- Maintain and update knowledge in their professional field.

The competence "Reveal the benefits of modern digital technologies and support students in using the achievements of modern digital technologies" is proposed to develop within the framework of the in-service training module "Modern technologies of teaching and learning", within which modern digital learning technologies would be covered. In the pandemic, distance learning technologies in general, and blended learning technologies in particular, have acquired particular relevance.

Competence "Maintain and update knowledge in their professional field" indicates that engineering and pedagogical workers understand the need to maintain and update knowledge in their professional field, there is a willingness to professionally develop throughout their lives. At the same time, there is no sufficient motivation for the implementation of this competence.

It should be especially noted that the engineering and pedagogical workers training needs analysis covers all 3 criteria for the correspondence (assessment) of engineering and pedagogical workers' competencies, but this does not mean that all of them should be achieved simultaneously. The engineering and pedagogical workers could develop at different rates and in different ways, focusing on three or four dimensions, or one of three components (professional; pedagogical; key general competences).

In general, the assessment of the existing competencies of the engineering and pedagogical worker is recommended to be carried out annually from June to June 15. It is proposed to assess the engineering and pedagogical workers' competencies with formal initiation of the competence assessment process by the HR department.

The annual assessment of the engineering and pedagogical workers professional and pedagogical competencies is a specially organized continuous process of monitoring and comprehensive analysis of the engineering and pedagogical workers key performance indicators. On the one hand, it will make it possible to identify the engineering and pedagogical workers training needs, on the other hand, through a systematic diagnosis of the quality of education, not only to identify, but also to improve the reserve opportunities for self-development of the creative potential of the engineering and pedagogical workers. The results of the annual assessment of competencies can be applied to the engineering and pedagogical workers who have worked continuously for more than 6 months in an educational institution.

The annual assessment of the engineering and pedagogical workers professional and pedagogical competencies is recommended to carry out on the basis of the results:

1. The engineering and pedagogical workers' self-assessment;

2. Evaluation by the experts; 
3. Survey of students, colleagues and administration.

In addition to annual assessment the engineering and pedagogical workers' competencies propose to provide assessment when hiring employee.

When applying for a job, the applicant should provide the following documents:

1. Resume;

2. The document on education, confirming the presence of both professional (that branch of the economy for which the students are trained in the educational institution) and pedagogical qualifications;

3. Documents confirming qualifications for work-based learning (certificate of internship, qualification certificate);

4. Letter of recommendation from the previous place of work.

Moreover within 5 working day from date of receipt of the application form, the applicant for the position of the engineering and pedagogical worker has to pass a self-assessment.

Then HR department arranges trial lecture or practical session. It is not necessary to involve students. The opinion of the experts will be decisive for assessing his competencies.

The trajectory of professional development is submitted to the applicant in Table 2.

Table 2. The engineering and pedagogical worker professional development trajectory.

\begin{tabular}{|c|c|c|}
\hline Level & Content & $\begin{array}{l}\text { Professional } \\
\text { development trajectory }\end{array}$ \\
\hline \multirow{3}{*}{$\begin{array}{l}\text { The engineering } \\
\text { and pedagogical } \\
\text { worker }\end{array}$} & $\begin{array}{l}\text { Qualification does not meet the } \\
\text { established requirements }\end{array}$ & Training \\
\hline & $\begin{array}{l}\text { It is required to expand the qualifications } \\
\text { of the engineering and pedagogical worker } \\
\text { to ensure his adaptation to the changed } \\
\text { conditions and to conduct new } \\
\text { professional activities }\end{array}$ & Retraining \\
\hline & $\begin{array}{l}\text { It is required to update of theoretical } \\
\text { knowledge and practical skills }\end{array}$ & $\begin{array}{l}\text { In-service training } \\
\text { Internship every } 3 \text { year }\end{array}$ \\
\hline
\end{tabular}

If the professional level of qualifications, for example, of an engineering and pedagogical worker does not correspond to his current position, for example, he has 5th level in the National Qualification Framework [7], but needs 6th level (bachelor's degree), the college can allow the teacher to obtain a bachelor's degree.

If the engineering and pedagogical workers does not have a pedagogical qualification, then the college can allow him to obtain additional pedagogical qualifications during six months based on the existing retraining system.

If the engineering and pedagogical workers has not been involved in the professional development programs in last 3 years, there is needs to improve the level of his professional and pedagogical knowledge and skills, as well as to update theoretical knowledge and practical skills with the increasing requirements to qualifications and needs to master the modern methods of solving professional problems, then the engineering and pedagogical worker is recommended to get the in-service training program.

If the engineering and pedagogical workers don't have experience of working at the enterprises of the industry, an internship in specialized enterprises is recommended for him.

\section{Conclusions}

The assessment of the engineering and pedagogical workers competencies must be specially organized continuous process of monitoring and comprehensive analysis of the engineering and pedagogical workers key performance indicators. On the one hand, it will make it 
possible to identify the engineering and pedagogical workers training needs, on the other hand, through a systematic diagnosis of the quality of education, not only to identify, but also to improve the reserve opportunities for self-development of the creative potential of the engineering and pedagogical workers.

The considered methodology is used the approach, according to which the engineering and pedagogical workers must meet the requirements of two professional standards: in the "Specialty", the "Pedagogy" and have to have general competencies.

The main outcomes of applying methodology are:

- Revealed the existing competencies of the engineering and pedagogical workers;

- The gap between existing and required professional competencies of the engineering and pedagogical workers has been determined;

- The trajectory of professional development of the engineering and pedagogical workers have been developed.

The methodology is interesting to the head of college, quality department, human resource department, training centers, the engineering and pedagogical workers, and trainers. They will be able to constantly monitor the level of professional competencies of the engineering and pedagogical workers, identify training needs.

The engineering and pedagogical workers can develop at different rates and in different ways, focusing on three or four dimensions, or one of three training needs components, by individual trajectory of professional development.

\section{References}

1. H. Moeini, Seminar.net - International journal of media, technology and lifelong learning, 4 (2008)

2. Achieving professional potential. Self-development using the 2014 professional standards. 157-197 Buckingham Palace Road, London SW1W 9SP 02037408280 www.et-foundation.co.uk

3. Education and Training Foundation. Training Needs Analysis, 2018. www.etfoundation.co.uk

4. Об утверждении «Методологии анализа потребности в обучении инженернопедагогического работника учебного заведения среднего профессионального образования» для пилотирования в Центрах передового опыта» [Приказ МОН КР / Принят 20.11.20 № 380/1]

5. Профессиональный стандарт «Монтаж и эксплуатация внутренних санитарнотехнических и вентиляционных устройств» [Электронный ресурс] Режим доступа: https://edu.gov.kg/ru/]

6. Профессиональный стандарт "Преподаватель среднего профессионального образования” [Электронный ресурс] Режим доступа: https://edu.gov.kg/ru/]

7. Об одобрении Национальной рамки квалификаций [Постановление ПКР/ Принят 18.09.20 №491/ [Электронный ресурс] Режим доступа: https://www.gov.kg/ru/npa/s/2709]

8. Training needs in the further education sector, ETF, www.et-foundation.co.uk. (2018)

9. Vocational Teacher Development Programme. Handbook, (2017-2018). https://www.haaga-helia.fi/en/haaga-helia-school-vocational-teacher-education

10. The power of demonstration. Supporting reform of professional development for vocational teachers and trainers. European Training Foundation, (2019)

11. A. MIklavčič, A. Camilleri, A. Pires, B. Savič, O. Chrást, D. Craig, D. Rasimavičienè, H. Esca-Scheuringer, M. Grdošić, M. Karpišek, N. Guthan, S. Feliciano. Apprenticeship Quality Toolkit. Knowledge Innovation Centre (Malta) Ltd., (2017) 
12. Методика профессионального обучения: учебное пособие для мастеров производственного обучения и наставников на производстве / отв. ред. В. И. Блинов. - М.: Издательство Юрайт, (2017).

13. Quality Apprenticeships: A Manual for Educational Organizations. ApprenticeshipQ, (2020)

14. Quality Apprenticeships: A Manual for Placement Providers. ApprenticeshipQ, (2020)

15. Work-Based Learning Policy Guide. Tennessee Department of Education, (2017)

16. R. Sweet. Work-based learning a handbook. ETF, (2014)

17. Профессиональный стандарт "Педагог профессионального обучения, профессионального образования и дополнительного профессионального образования" [Приказ Министерства труда и социальной защиты РФ / Принят 8 сентября 2015 г. N 608н] Режим доступа: http://fgosvo.ru/01.004.pdf

18. Профессиональный стандарт «Педагог» [Приказ Председателя Правления Национальной палаты предпринимателей Республики Казахстан «Атамекен» № 133 от 8 июня 2017 года] Режим доступа: https://atameken.kz/uploads/content/files]

19. ETF (European Training Foundation), Work-based Learning: Benefits and Obstacles. A Literature Review for Policy Makers and Social Partners in ETF Partner Countries, ETF, Turin, (2013).

20. OECD (Organisation for Economic Cooperation and Development), Developing Skills in Central Asia through Better VET Systems, Paris, (2013) 